\title{
OVERFLOWING TESTS AT THE POLISH DREDGDIKES RESEARCH DIKE - STABILITY OF THE DIKE SURFACE AGAINST EROSION
}

\author{
Jan OLSCHEWSKI ${ }^{\mathrm{a}}$, Stefan CANTRÉa ${ }^{\text {, Fokke SAATHOFFa, }}$ \\ Remigiusz DUSZYŃSKI ${ }^{\mathrm{b}}$, Rafał OSSOWSKI ${ }^{\mathrm{b}}$ \\ ${ }^{a}$ Chair of Geotechnics and Coastal Engineering, Universität Rostock, Justus-von-Liebig-Weg 6, \\ 18059 Rostock, Germany \\ ${ }^{b}$ Geotechnics, Geology and Maritime Engineering, Gdansk University of Technology, \\ ul. Narutowicza 11/12, 80-233 Gdansk, Poland
}

Received 19 June 2015; accepted 16 July 2015

\begin{abstract}
In the project DredgDikes the different research dike embankments were tested with respect to overflowing water induced erosion. Therefore, flumes were installed on the land side embankments in which the effect of overflowing water on the vegetated surface was investigated. On the Polish DredgDikes research dike near Gdansk, Poland, two parallel flumes were installed and the surface of the dike made of different mixtures of ash, silt and sand as well as clay was tested both in vegetated and unvegetated state. The results showed that the grass sods placed on the dike embankment had a comparably low erosion stability, particularly if placed directly on the hardened ash/silt dike cover with better results if placed on a clay cover, while the ash/silt mixture showed a high erosion resistance without vegetation. This results in the recommendation to use a thicker vegetation layer on top of the ash composite dike if the vegetation shall account for the erosion resistance or else, that even if the grass cover is washed away, a very solid cover made of the ash composite can withstand an overflowing event for considerable time.
\end{abstract}

Keywords: hydraulic structures, ash composites, dike embankment, erosion resistance, flume experiments, levee.

\section{Introduction}

In the project DredgDikes (Saathoff et al. 2015a) two large-scale research dikes were constructed to investigate fine-grained dredged materials as well as sand ash composites for the application in dike construction. In Poland the major part of energy production is still coal combustion power plants and thus there is a surplus of combustion residues such as ashes and slag. Therefore, the Gdansk research dike was built from sand and silt in combination with different ashes to investigate the possibility to recover these residues in dikes which need to be newly built, reconstructed or renovated along many waters in Poland.
The different materials were intensively studied in the laboratory before and after installation in the research dike (Balachowski, Sikora 2013), which was both used to investigate the quality and amount of seepage when loaded by a high water level on one side and to determine the stability of the dike cover against overflowing water. The dike cover was made of two different materials and an additional vegetation cover.

The overflowing tests were carried out using two flumes installed on the land side embankment to evaluate the erosion resistance of the ash composites in comparison to clay as well as greening and overall stability issues. The flumes were designed in accordance

Corresponding author:

J. Olschewski E-mail: jan.olschewski@uni-rostock.de 
to ASTM D6460-12 (2008), using the same setup as in the overflowing tests on the German DredgDikes research dike (Saathoff et al. 2015b). This paper presents the results of the overflowing tests of both the vegetated and unvegetated surfaces of the Gdansk research dike which were performed in September 2014, including a comparison of evaluation methods to rate the erodibility.

\section{Investigated materials}

In the Polish DredgDikes research two basically different types of ash were used: A bottom ash mixed with dredged sand from the Vistula river mouth was installed in the dike core and a mixture of different ashes (fluid ash, fly ash) and other binders (Tefra ${ }^{\circledR}$ ) was used in parts of the dike cover while the rest of the cover consists of clay.

In a preliminary laboratory investigation the optimum ash/sand mixture of a composite to be applied at the test site was chosen. In the tests basic soil properties, compressibility and soil strength, compaction and perme-ability parameters were determined for the separate materials (sand, ash) as well as for mixtures with different ash content. Table 1 shows a compilation of the properties of the materials investigated in Gdansk.

The proportion of components in the test dike was chosen based on initial tests on the dredged sand: it was examined, how the properties of the mixture are influenced by the variation of the percentage of ash. For the mixtures, the portion of ash was varied from $0 \%$ to $100 \%$ in steps of $10 \%$. Figure 1 shows the maximum dry density and optimal water content for

Table 1. Selected geotechnical properties of the materials used in the Gdansk DredgDikes research dike

\begin{tabular}{|l|c|c|c|}
\hline & clay & ash/silt & $\begin{array}{c}\text { ash/sand } \\
70 / 30\end{array}$ \\
\hline Total unit weight $\gamma\left[\mathrm{kN} / \mathrm{m}^{3}\right]$ & 18 & 16 & 13 \\
Sat. unit weight $\gamma_{\text {sat }}\left[\mathrm{kN} / \mathrm{m}^{3}\right]$ & 21 & 20 & 16.3 \\
Hydraulic conductivity $\mathrm{k}[\mathrm{m} / \mathrm{s}]$ & $1 \mathrm{E}-7$ & $1 \mathrm{E}-7$ & $1 \mathrm{E}-5$ \\
Void ratio e [-] & 0.79 & 0.64 & 0.69 \\
Cohesion c $\left[\mathrm{kN} / \mathrm{m}^{2}\right]$ & 30 & 50 & 5 \\
Angle of internal friction $\left.\varphi{ }^{\circ}\right]$ & 25 & 20 & 37 \\
Young's modulus E $\left[\mathrm{kN} / \mathrm{m}^{2}\right]$ & $1.5 \mathrm{E} 4$ & $3 \mathrm{E} 4$ & $2.3 \mathrm{E} 4$ \\
Poisson's ratio [-] & 0.35 & 0.3 & 0.25 \\
\hline
\end{tabular}

the different mixtures. The optimum water content increases while the density decreases with increasing ash content.

The void ratio e was determined in the oedometric tests. It increases with increasing ash content. The angle of internal friction and cohesion were derived from direct shear tests. The cohesion increases with an ash content of more than $60 \%$ while the angle of friction then decreases, as shown in Figure 2.

Finally, an optimum mixture of 70/30 (ash/sand) was chosen for the research dike construction. The mixture has a relatively high permeability coefficient (Table 1). However, it was assumed that the hydraulic conductivity will decrease over time because of the cementation due to the pozzolanic properties of the coal ashes. The verification in samples taken from the dike core showed about $40 \%$ decrease of the permeability coefficient after 180 days.

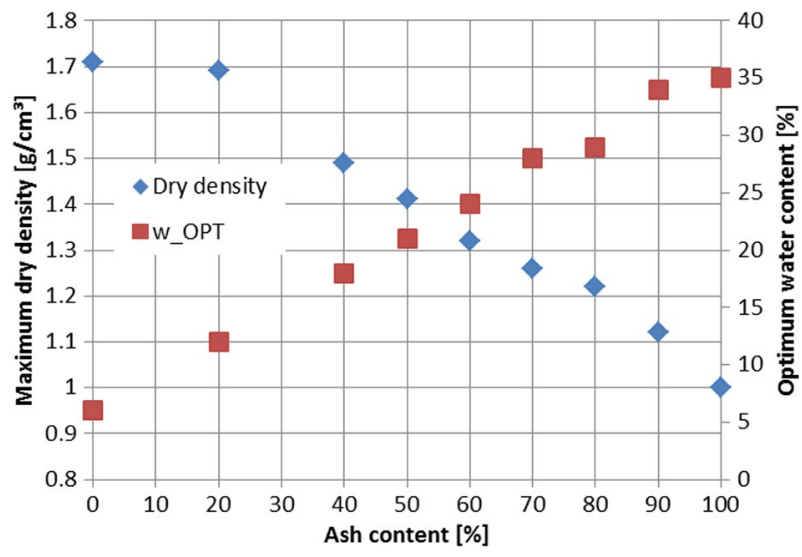

Fig. 1. Maximum dry density and optimum water content of the different sand ash mixtures

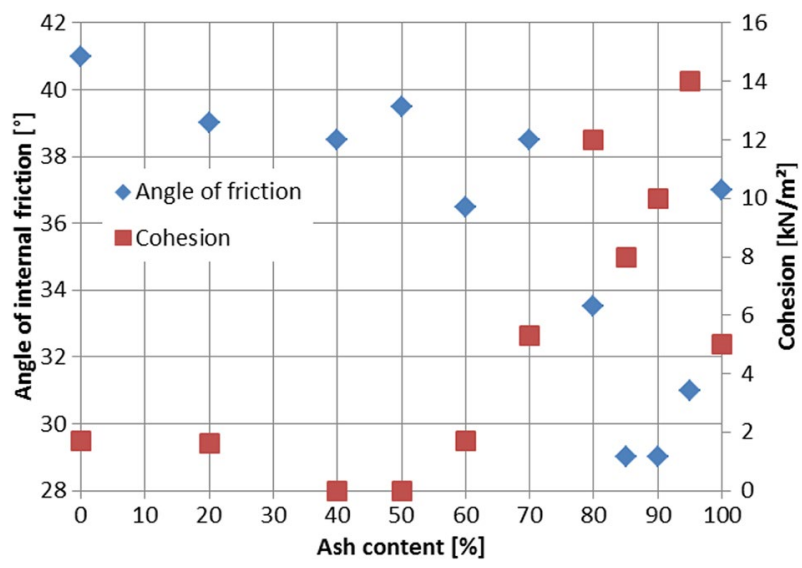

Fig. 2. Angle of internal friction and cohesion of the different sand ash mixtures 


\section{Experimental dike}

The $3 \mathrm{~m}$ high research dike located in Wiślinka/ Trzcińsko on the bank of Vistula River ca. $20 \mathrm{~km}$ outside the City of Gdańsk was completed in the summer of 2012 (Sikora, Ossowski 2013). It has a slope inclination of $1 \mathrm{~V}: 2 \mathrm{H}$ and a $3 \mathrm{~m}$ wide crest. The $4 \mathrm{~m}$ wide test segment of the $24 \mathrm{~m}$ long dike is separated by sheet pile walls to obtain two-dimensional plane conditions for seepage and overtopping tests with a controlled water level (Fig. 3).

The research dike is composed of three different materials (Table 1):

- the dike core is made of a mixture of bottom ash and dredged sand (referred to as ash/sand);

- clay in $50 \mathrm{~cm}$ layer thickness as upstream cover;

- a mixture of ash, silt and Tefra ${ }^{\circ}$ (a special fluid ash mixture) in a $30 \mathrm{~cm}$ layer as downstream cover (referred to as ash/silt).

Figure 4 shows a cross-section with the different materials as planned. During the tests it was found, however, that the clay cover was reaching over the crest into the upper third of the downstream face.

To focus on the seepage within the dike, its bottom was sealed against the permeable ground by

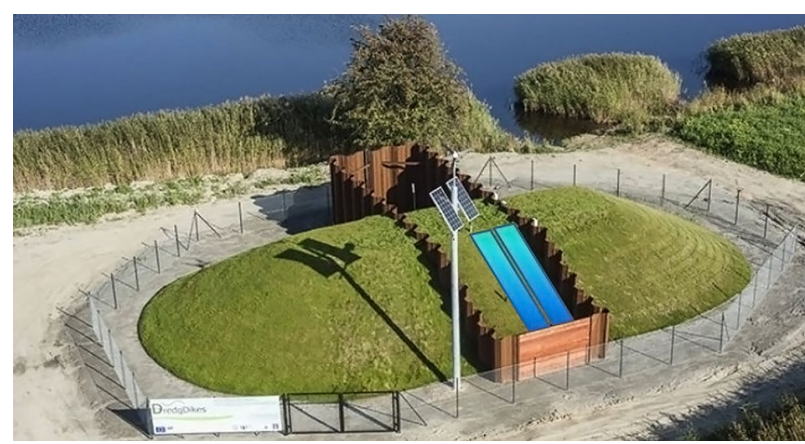

Fig. 3. Gdansk research dike with test section and location of flume 1 (right) and flume 2 (left) a $0.5 \mathrm{~m}$ thick clay liner. A high water level of $2.5 \mathrm{~m}$ could be maintained until steady flow within the dike body was achieved. In the dike core 24 soil moisture probes have been installed to measure the seepage line. The dense sensor raster allows the comparison with numerical simulations (Ossowski et al. 2014). Four piezometers are used to verify the sensor data. The greening was realized with rolled sod placed directly on the dike cover made of a silt/ash composite and a clay, a solution that cannot be recommended because of the poor water and nutrient supply in the thin soil layer of the rolled sod.

\section{Overflowing tests}

\subsection{Test set-up and measurement techniques}

Based on a modified NTPEP (2013) test set-up two parallel flume channels were installed on the downstream embankment of the research dike. Figure 5 shows the basic experimental set-up. Each flume had an inner width of $0.6 \mathrm{~m}$ and nine test sections. The flumes were made of construction form elements and each of these was fixed onto the slope and sealed with construction foam. Wooden slats served as markings for the individual test sections (Olschewski et al. 2014).

On the dike crest the water inlets for discharge control were placed. The water delivery system included the Vistula River (as a reservoir), a pump and flexible tubes, the sheet pile basin, steel shutters at the flume inlets and a runoff channel (Fig. 6).

The discharge for the overflowing experiments was regulated on the dike crest with steel shutters. Depending on the polder filling height and the opening width of the shutter a flume target discharge was adjusted. For peak discharges the pump delivered up to $750 \mathrm{~m}^{3} \mathrm{~h}^{-1}$.

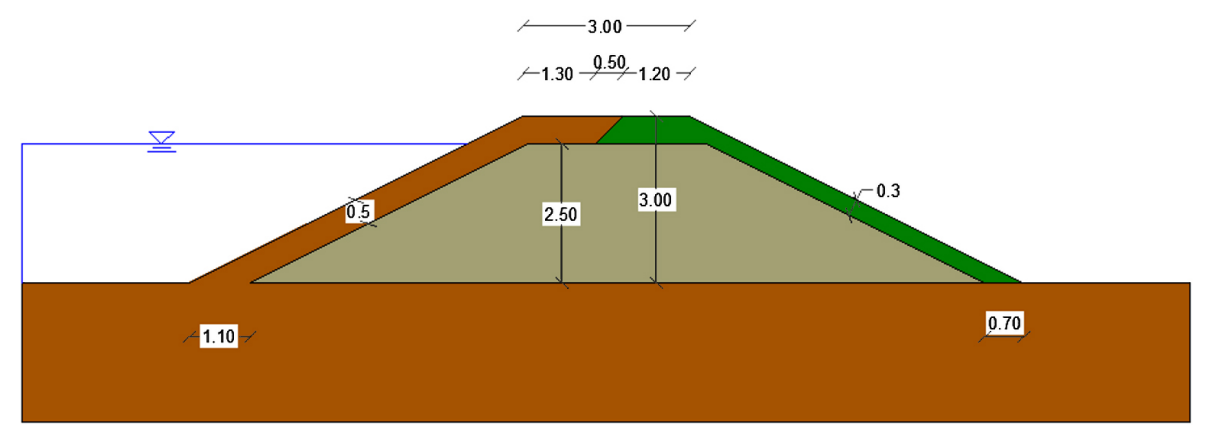

Fig. 4. Cross-section of the Gdansk research dike in the test section with the planned division of cover materials: clay (brown) on the upstream side and silt/ash composite (green) on the downstream side 


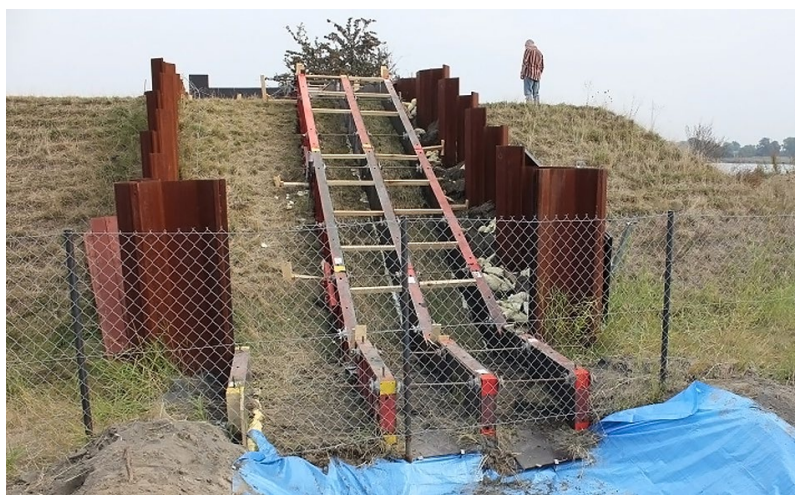

Fig. 5. Basic experimental set-up of the Gdansk flume system

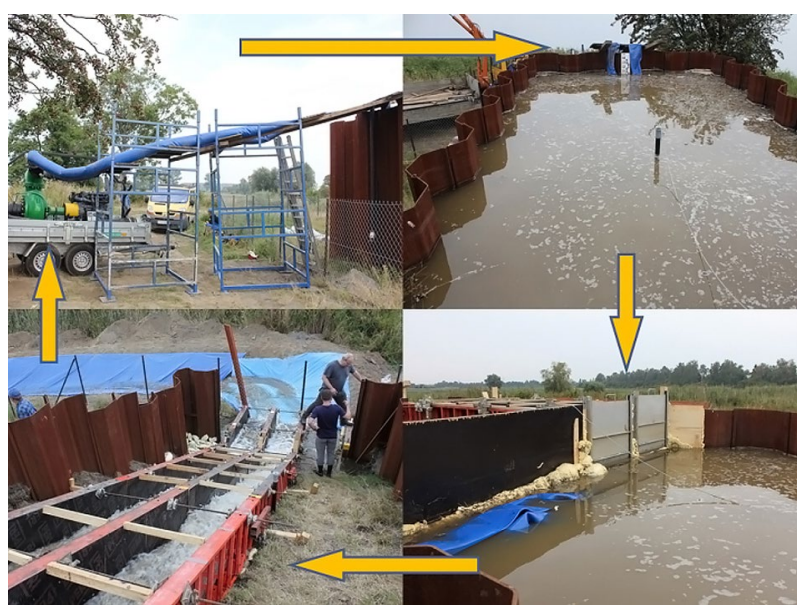

Fig. 6. Water cycle for the overflowing tests: pump, reservoir, shutters and flumes

Both the flow velocity and runoff depth were measured during the experiments. For the flow velocity a portable magnetic-inductive sensor was used on the dike crest and in every test section on the slope. The run-off depth on the dike crest and on the slope was measured using a standard ruler.

The erosion on the embankment surface was determined with a pin-profiler (Olschewski et al. 2014). Additionally, each test section was evaluated with grades between 1 and 4 before and after each overflowing test according to Van der Meer et al. (2010).

Photographic images of each test section were made before and after each test stage, which have been used to compare the slope surface conditions, e.g. regarding the vegetation coverage.

\subsection{Test procedure and analysis}

The experiments were carried out as follows:

- the initial state of the embankment was recorded (pin-profiling, marking, image and written documentation),
- the discharge was slowly increased by opening the shutters within approx. five minutes, to minimise the shock load on the soil surface,

- 45 minutes (vegetated) respectively 6 to $10 \mathrm{mi}$ nutes (unvegetated) overflow with the target discharge,

- the flow velocity and discharge depth were measured in each test section and on the dike crest

- the shutters were closed, the residual water drained,

- the final state of the dike embankment was recorded including pin-profiling, marking, image, and written documentation (also used as initial recording for the subsequent flow level or final recording for the whole test series), and

- the measured data was transferred to a record sheet.

The target discharges (TD) had to be chosen before the start of the test series. For high discharges the limiting factors were the performance of the pump and the height of the sheet pile basin above the dike crest. Tables 2 and 3 contain compilations of the mean discharge rates and the dependent variables measured and computed in September 2014.

The test record sheets were analysed afterwards. Therefore, several values were calculated or recalculated to control the target values: (i) soil loss per testsection and cumulated for the whole flume, (ii) discharge, and (iii) shear stress.

\section{Results and evaluation}

Four large-scale field test series with a total of 18 individual overflowing tests were carried out at the Gdansk research dike in September 2014, including 10 and 8 short-term tests on the vegetated and unvegetated slopes respectively. The results are compiled in Tables 2 to 7. During the overflowing experiments it was observed, that the clay cover was installed across the crest and down on the downstream slope on approximately $2.5 \mathrm{~m}$ of the upper embankment (see above). Due to this, considerable differences of the cumulated soil loss values between the upper and lower parts of the flumes were measured. Therefore, the results of the two different areas in the flumes are presented separately for the upper test sections " $1-3$ " and the lower test sections "4-9" (Tables 6 and 7).

The soil loss rates were compared with the shear stresses and the flow velocities from each flume. 
Table 2. Mean unit discharges (q), measured and computed hydraulic values (flow velocity (v), discharge depth (h), shear stress $(\tau))$, Froude \& Reynolds numbers, vegetated, September 2014

\begin{tabular}{|c|c|c|c|c|c|c|}
\hline Stage & $\begin{array}{c}\varnothing \mathrm{q} \\
{\left[\mathrm{s}^{-1} \mathrm{~m}^{-1}\right]}\end{array}$ & $\begin{array}{c}\varnothing \mathrm{v} \\
{\left[\mathrm{ms}^{-1}\right]}\end{array}$ & $\begin{array}{c}\varnothing \mathrm{h} \\
{[\mathrm{m}]}\end{array}$ & $\begin{array}{c}\varnothing \tau \\
{[\mathrm{Pa}]}\end{array}$ & $\begin{array}{c}\mathrm{Fr}^{(1)} \\
{[-]}\end{array}$ & $\begin{array}{c}\mathrm{Re}^{(2)} \\
{[-]}\end{array}$ \\
\hline 1 & 52 & 1.3 & 0.041 & 199 & 2.05 & 40,653 \\
$2 / 3$ & 97 & 1.86 & 0.053 & 260 & 2.57 & 73,255 \\
4 & 200 & 2.9 & 0.071 & 350 & 3.46 & 146,736 \\
5 & 233 & 3.38 & 0.076 & 373 & 3.91 & 180,234 \\
\hline
\end{tabular}

Notes: ${ }^{(1)} \operatorname{Fr}<1$ : subcritical, $\operatorname{Fr}>1$ : supercritical; ${ }^{(2)} \operatorname{Re} \leq 2320$ : laminar, $\operatorname{Re} \geq 2320$ : turbulent.

Table 3. Mean unit discharges (q), measured and computed hydraulic values (flow velocity (v), discharge depth (h), shear stress $(\tau)$ ), Froude \& Reynolds numbers, unvegetated, September 2014

\begin{tabular}{|c|c|c|c|c|c|c|}
\hline Stage & $\begin{array}{c}\varnothing \mathrm{q} \\
{\left[1 \mathrm{~s}^{-1} \mathrm{~m}^{-1}\right]}\end{array}$ & $\begin{array}{c}\varnothing \mathrm{v} \\
{\left[\mathrm{ms}^{-1}\right]}\end{array}$ & $\begin{array}{l}\varnothing \mathrm{h} \\
{[\mathrm{m}]}\end{array}$ & $\begin{array}{l}\varnothing \tau \\
{[\mathrm{Pa}]}\end{array}$ & $\begin{array}{l}\text { Fr } \\
{[-]}\end{array}$ & $\begin{array}{l}\mathrm{Re} \\
{[-]}\end{array}$ \\
\hline 1 & 41 & n.m & 0.020 & 98 & n.c. ${ }^{(1)}$ & n.c. (1) \\
\hline 2 & 116 & n.m. ${ }^{(1)}$ & 0.050 & 245 & n.c. ${ }^{(1)}$ & n.c. (1) $^{(1)}$ \\
\hline 3 & 15 & n.m. ${ }^{(1)}$ & 0.0 & 261 & n.c. ${ }^{(1)}$ & n.c. ${ }^{(1)}$ \\
\hline 4 & 172 & 2.89 & 0.051 & 250 & 4.08 & 110,868 \\
\hline 5 & 204 & n.m. ${ }^{(1)}$ & 0.066 & 321 & n.c. ${ }^{(1)}$ & n.c. ${ }^{(1)}$ \\
\hline 6 & 500 & 6.67 & 0.077 & 378 & 7.66 & 359,417 \\
\hline
\end{tabular}

Note: ${ }^{(1)}$ not measurable / not computable.

Table 4. Max. cumulative soil loss (CSL) and hydraulic forces, short-term tests series, vegetated, September 2014

\begin{tabular}{|c|c|c|c|c|c|}
\hline Flume & $\begin{array}{c}\text { Max. CSL } \\
{[\mathrm{cm}]}\end{array}$ & $\begin{array}{c}\text { Max. q } \\
{\left[\mathrm{ls}^{-1} \mathrm{~m}^{-1}\right]}\end{array}$ & $\begin{array}{c}\text { Max. v } \\
{\left[\mathrm{ms}^{-1}\right]}\end{array}$ & $\begin{array}{c}\text { Max. h } \\
{[\mathrm{m}]}\end{array}$ & $\begin{array}{c}\text { Max. } \tau \\
{[\mathrm{Pa}]}\end{array}$ \\
\hline 1 & 7.9 & 249 & 3.27 & 0.079 & 386 \\
2 & 1.6 & 217 & 3.49 & 0.073 & 359 \\
\hline
\end{tabular}

Figures 8, 10, 11 and 12 show the results of the vegetated slope while Figures 9, 13, 14 and 15 present the results for the unvegetated conditions, both for the whole flume length and separated into upper and lower section. The shear stress results were chosen to be presented here, since they provide good information regarding the erosion resistance. In addition, Figure 15 shows an example of the image documentation of the slope surface development in flume 1. Due to the scattered measure-ment results, the definition of a "best fit" trend line through the data points was not reasonable. Instead, a linear trend line was chosen for all charts to define the flume specific soil loss functions. A higher inclination of the trend line stands for a higher erosion rate.

The results for the vegetated slopes show low values of cumulated soil loss (CSL) during discharge stages $3 / 4\left(\mathrm{q}_{\max } \approx 200 \mathrm{ls}^{-1} \mathrm{~m}^{-1}\right)$. The CSL value of $\approx 2 \mathrm{~mm}$ in flume 1 at a shear stress of $\tau \approx 350 \mathrm{~Pa}$ is
Table 5. Max. cumulative soil loss (CSL) and hydraulic forces, short-term tests series, unvegetated, September 2014

\begin{tabular}{|c|c|c|c|c|c|}
\hline Flume & $\begin{array}{l}\text { Max. CSL } \\
{[\mathrm{cm}]}\end{array}$ & $\underset{\left[1 \mathrm{~s}^{-1} \mathrm{~m}^{-1}\right]}{\operatorname{Max} . \mathrm{q}}$ & $\begin{array}{l}\text { Max. v } \\
{\left[\mathrm{ms}^{-1}\right]}\end{array}$ & $\begin{array}{l}\text { Max. h } \\
{[\mathrm{m}]}\end{array}$ & $\begin{array}{c}\text { Max. } \tau \\
{[\mathrm{Pa}]}\end{array}$ \\
\hline $1^{(1)}$ & 3.3 & 115 & n.m. ${ }^{(2)}$ & 0.050 & 245 \\
\hline 2 & 3.0 & 500 & 6.67 & 0.077 & 378 \\
\hline
\end{tabular}

Notes: ${ }^{(1)}$ Only two discharge stages; ${ }^{(2)}$ Not measurable.

Table 6. Max. cumulative soil loss (CSL) and hydraulic forces, short-term tests series with focus on the upper (" $1-3$ ") and lower (“4 - 9") test sections, vegetated, September 2014

\begin{tabular}{|c|c|c|c|c|c|}
\hline Flume & $\begin{array}{c}\text { Max. CSL } \\
{[\mathrm{cm}]}\end{array}$ & $\begin{array}{c}\text { Max. q } \\
{\left[\mathrm{ls}^{-1} \mathrm{~m}^{-1}\right]}\end{array}$ & $\begin{array}{c}\text { Max. v } \\
{\left[\mathrm{ms}^{-1}\right]}\end{array}$ & $\begin{array}{c}\text { Max. h } \\
{[\mathrm{m}]}\end{array}$ & $\begin{array}{c}\text { Max. } \tau \\
{[\mathrm{Pa}]}\end{array}$ \\
\hline $1: 1-3$ & 1.0 & 249 & 2.74 & 0.097 & 474 \\
$1: 4-9$ & 11.1 & 249 & 3.49 & 0.070 & 343 \\
$2: 1-3$ & 1.2 & 217 & 2.61 & 0.093 & 457 \\
$2: 4-9$ & 1.8 & 217 & 3.64 & 0.064 & 313 \\
\hline
\end{tabular}

Table 7. Max. cumulative soil loss (CSL) and hydraulic forces, short-term tests series with focus on the upper ("1 - 3") and lower (“4 - 9”) test sections, unvegetated, September 2014

\begin{tabular}{|c|c|c|c|c|c|}
\hline Flume & $\begin{array}{c}\text { Max. CSL } \\
{[\mathrm{cm}]}\end{array}$ & $\begin{array}{c}\text { Max. q } \\
{\left[\mathrm{ls}^{-1} \mathrm{~m}^{-1}\right]}\end{array}$ & $\begin{array}{c}\text { Max. v } \\
{\left[\mathrm{ms}^{-1}\right]}\end{array}$ & $\begin{array}{c}\text { Max. h } \\
{[\mathrm{m}]}\end{array}$ & $\begin{array}{c}\text { Max. } \tau \\
{[\mathrm{Pa}]}\end{array}$ \\
\hline $1: 1-3$ & 6.8 & 115 & n.m..$^{(1)}$ & 0.050 & 245 \\
$1: 4-9$ & 1.8 & 115 & n.m..$^{(1)}$ & 0.050 & 245 \\
$2: 1-3$ & 3.5 & 500 & 6.92 & 0.098 & 482 \\
$2: 4-9$ & 2.7 & 500 & 7.00 & 0.068 & 333 \\
\hline
\end{tabular}

Note: ${ }^{(1)}$ not measurable

a very good result. However, at the highest discharge level 5 the slope surface suddenly failed: the entire top layer including vegetation slipped away in test sections 4 to 9 on top of the ash/silt cover in the lower part of the embankment (Fig. 7). This explains the sudden and steep rise of the regression lines in Figures 7, 9 and 11. It also leads to the assumption that the connection between the vegetation layer and the dike cover was insufficient or even missing. The slope surface in flume 2, in the contrary, withstood the high forces. Here, a CSL of approximately $1.6 \mathrm{~cm}$ occurred at a shear stress of $\tau \approx 360 \mathrm{~Pa}$. Still, this value exceeds the limit recommended in ASTM D6460-12 (2008) $\left(\mathrm{CSL}_{\max }=1.27 \mathrm{~cm}\right)$. Both test series show the initiation of erosion at a shear stress of $\tau \approx 200 \mathrm{~Pa}$.

After the failure in flume 1, the vegetation layer inside the flumes was removed and overflowing experiments were carried out directly on the clay (sections 1 to 3 ) and on the ash/silt composite (sections 4 to 9). In both flumes erosion started at a shear stress of $\tau \approx 100 \mathrm{~Pa}$ (Fig. 8). After two discharge levels in flume 1 a large part of the clay layer slipped away and this test series was cancelled. The reasons for the big 
amount of soil loss were the installed instrumentation for seepage measurement at exactly this location including the related wiring and a partly only slightly compacted cover. The material in flume 2 withstood six discharge stages, although the resulting
$\mathrm{CSL} \approx 3 \mathrm{~cm}$ was higher than the ASTM recommendation. Particularly in flume 2 it can be noticed that after the first discharge level a relatively large amount of soil was removed, but in the course of the following discharge levels the rise of cumulated soil loss is

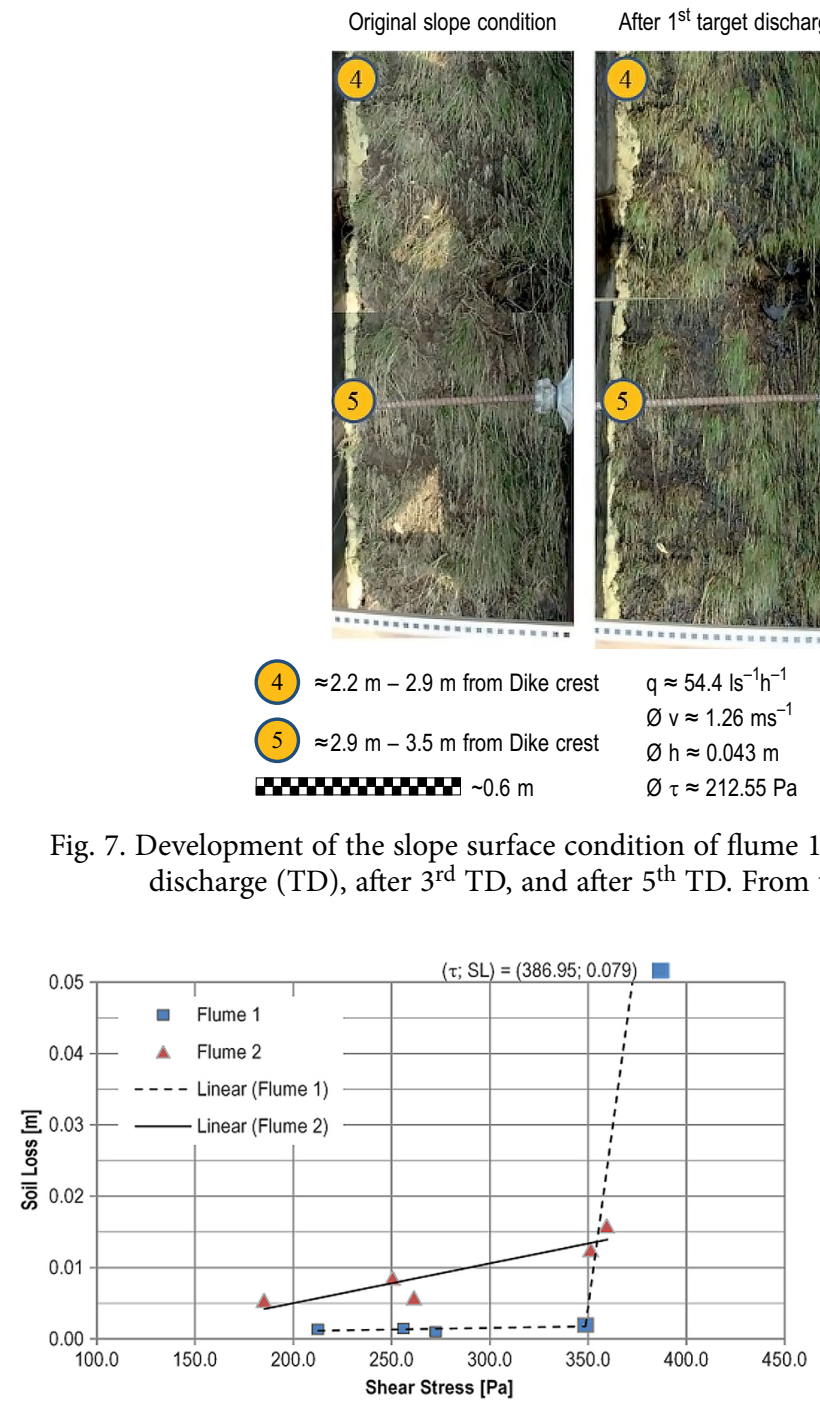

Fig. 8. Erosion rates flumes 1 \& 2 (vegetated); soil loss and shear stress, steep trend line $=$ high erosion rate, September 2014

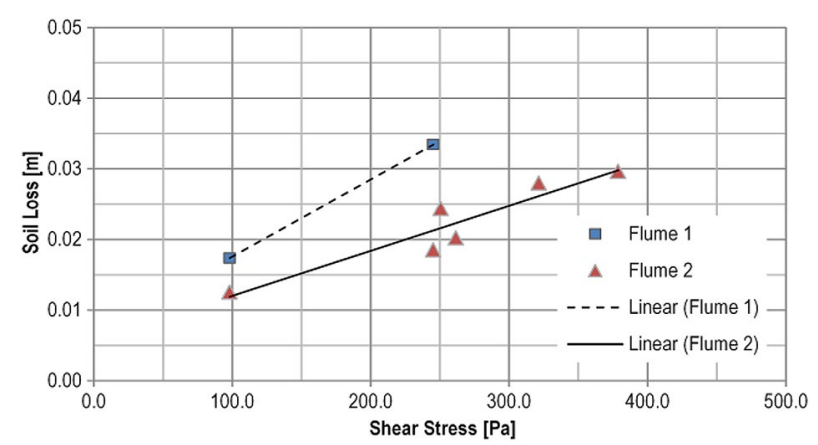

Fig. 9. Erosion rates flumes 1 \& 2 (unvegetated); soil loss and shear stress, steep trend line $=$ high erosion rate, September 2014

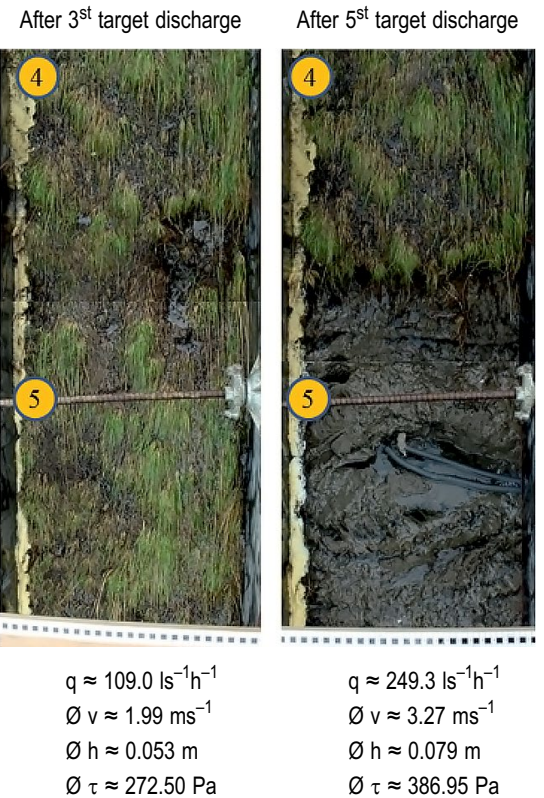

Fig. 7. Development of the slope surface condition of flume 1 sections 4 and 5 . From left to right: initial state, after $1^{\text {st }}$ target discharge (TD), after $3^{\text {rd }}$ TD, and after $5^{\text {th }}$ TD. From toe to the crest: flow direction / numbered test sections

only moderate. This is illustrated by the modest slope of the regression lines in Figures 9 and 14.

An important disadvantage of erosion measurements with a pin profiler is that the erosion is measured only at a few discrete (here: five) points in the upstream part of a test sections used to compute an average value for the whole test section. To overcome this drawback, every test section was additionally rated with the erosion numbers 1 to 4 before and after each flow event. Although there is no quantitative determination of soil loss, this method has the advantage that the condition of the whole surface can be described. The erosion numbers were then compared with the shear stresses for vegetated and unvegetated slope conditions (Figs 12, 15).

\section{Discussion}

The results for flumes 1 and 2 are very different, particularly because the surface of flume 1 was impaired by installed moisture sensors and their wiring together with a low compaction above these areas (e.g. after refilling the installation holes). Therefore, the two flumes are discussed separately. 


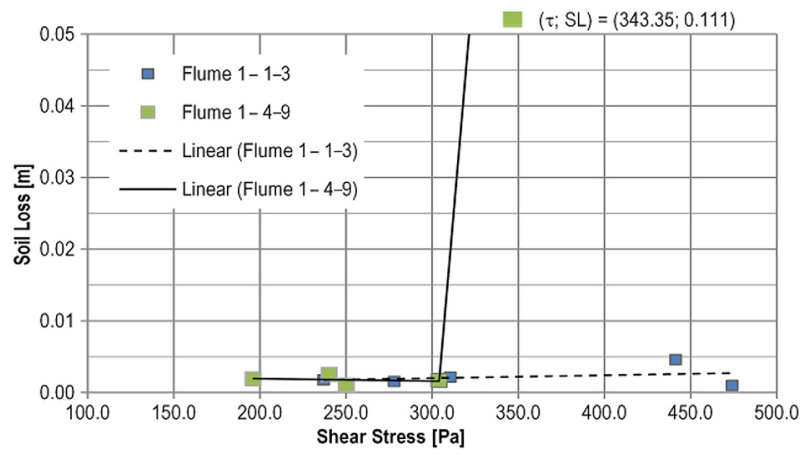

Fig. 10. Erosion rates flume 1 (vegetated); soil loss and shear stress, steep trend line $=$ high erosion rate, focus on the upper

(“1-3”) and lower (“4-9”) flume parts, September 2014

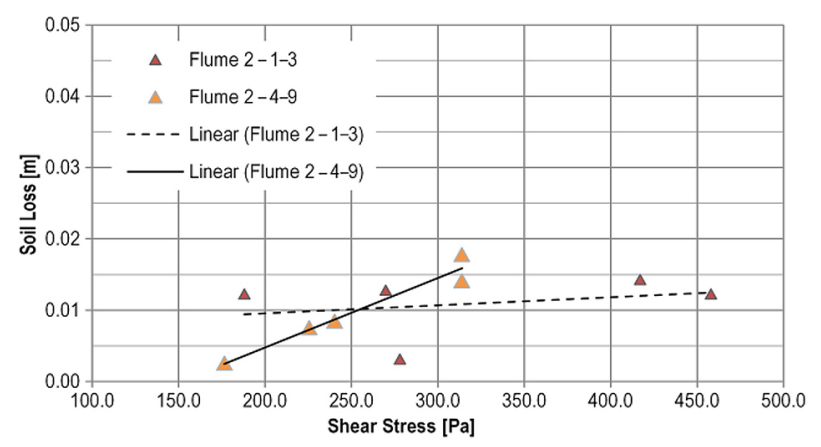

Fig. 11. Erosion rates flume 2 (vegetated); soil loss and shear stress, steep trend line $=$ high erosion rate, focus on the upper

(“1-3”) and lower (“4-9”) flume parts, September 2014

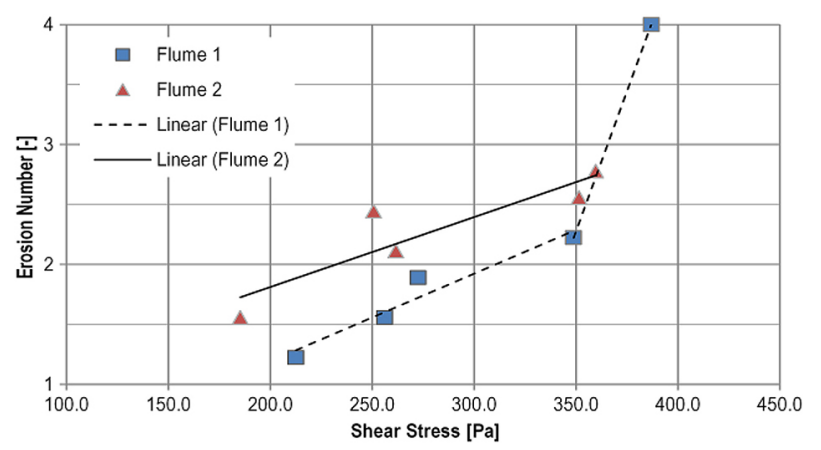

Fig. 12. Erosion numbers flumes $1 \& 2$ (vegetated); steep trend line $=$ high erosion rate, Sept 2014

In flume 1 the turf cover failed much earlier than in flume 2 due to partly low material compaction above the installed sensors. The failure of flume 1 is shown in Figure 7. A good compaction of the fine-grained ash composite up to the surface is vitally important for a safe construction. In addition, it could be shown, that the ash/silt composite was more stable in the impaired areas after removal of the vegetation than the clay.

In flume 2 both cover materials were equally well compacted and thus the grass cover remained stable over a longer period of time and up to a higher dis-

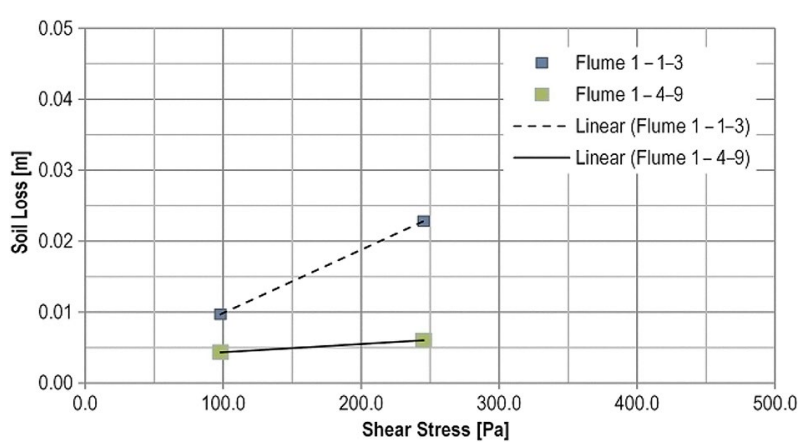

Fig. 13. Erosion rates flume 1 (unvegetated); soil loss and shear stress, steep trend line $=$ high erosion rate, focus on the upper ("1-3") and lower (“4-9") flume parts, September 2014

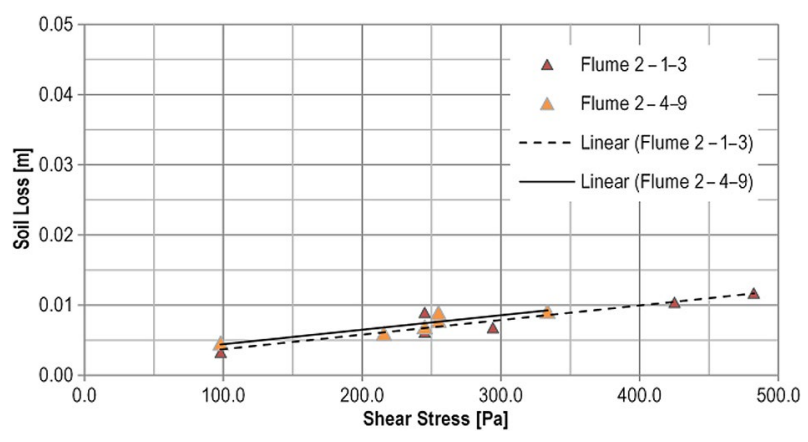

Fig. 14. Erosion rates flume 2 (unvegetated); soil loss and shear stress, steep trend line $=$ high erosion rate, focus on the upper (“1-3”) and lower (“4-9”) flume parts, September 2014

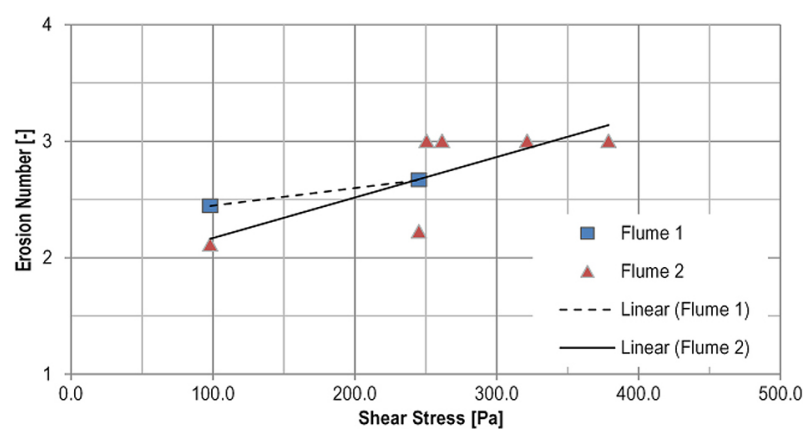

Fig. 15. Erosion numbers flumes $1 \& 2$ (unvegetated); steep trend line $=$ high erosion rate, September 2014

charge load. After the removal of the vegetation, the flat surfaces of both materials did not show a measurable difference (Fig. 14).

This leads to the assumption that both materials provide the same level of safety against erosion regarding overflowing water in a well-compacted state while the ash/silt composite performs better in case of construction-conditioned impairments. This may also be larger stones or other foreign substances in the clay material. In the end, the pozzolanic ash composite showed a higher overall stability against erosion. 
Another important issue is the use of rolled turf on the two different cover materials. The connection between the turf and the clay was considerably better (due to roots penetrating the clay and the high adhesion between clay and top soil/turf) than that between turf and ash composite. No roots penetrated the ash composite (Fig. 16). Thus it is not recommended to use rolled turf for dike cover greening if ash composites are used in the dike cover layer. The different cover materials also resulted in a difference in vegetation development due to medium (clay) and no (ash composite) water supply from below. Particularly on the southern embankment the turf failed during the first summer because the thin layer of top soil could not support the turf (not even on top of the clay). Therefore, a top soil layer of $20-40 \mathrm{~cm}$ thickness is recommended when installing an ash composite as dike cover material. For this, the benching technique is recommended to stabilise the top soil on the compacted ash composite or else to use a geosynthetic erosion control mat to reinforce the top soil on the embankment.

A further important aspect is the underground condition at the dike toe. In case of the research dike the connection between the compacted clay liner that served as an impermeable ground and the ash/ silt body/cover material was weak and thus a slip line developed quickly during the overflowing test and the dike toe failed (Fig. 17). This may be mitigated by embedding the dike cross-section including the cover material into the ground or by using technical help such as geosynthetic erosion control mat or reinforcement product.

The lesson learned from the installed instrumenta-tion and low compaction above is that the surface of both clay and ash/silt cover material needs to be well compacted over the whole surface before a top soil for the vegetation layer is applied.

\section{Conclusions}

The following weaknesses of the large-scale field experiments at the Gdansk DredgDikes research dike can be summarised: (i) the installed instrumentation triggered erosion and the failure of the vegetation layer in flume 1, (ii) the connection between the vegetation layer and the ash/silt was weak (slip plane), (iii) the connection between the ash/silt cover and the underground at the dike toe was weak (slip plane), (iv) the accurate measurement of discharge depth and

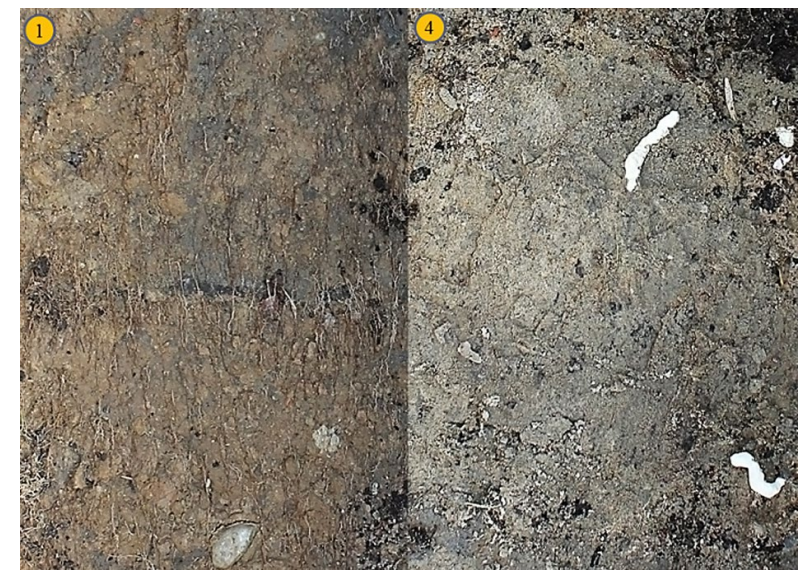

Fig. 16. Root penetration at the unvegetated slope surface. Depending on the subsoil the roots cling into the surface (clay layer, left) or almost not (ash/silt mixture, right). Flume 2, test sections 1 and 4 , original unvegetated conditions

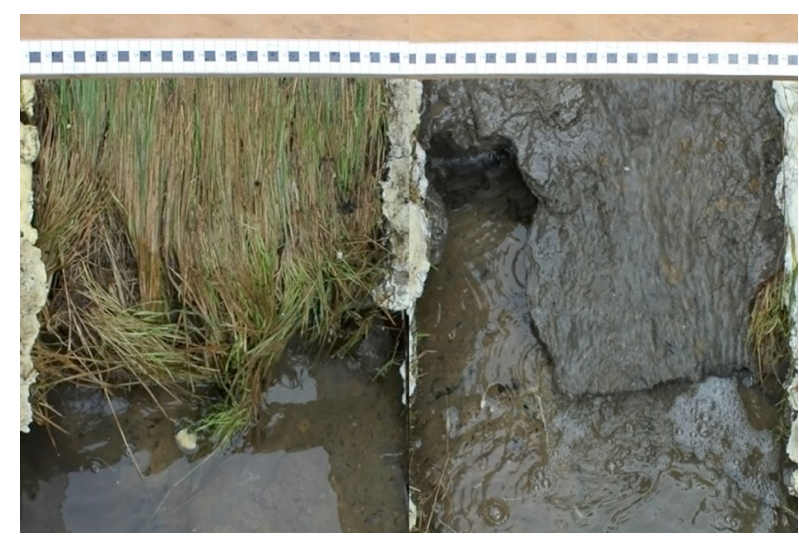

Fig. 17. Dike toe. Clay liner underneath the dike, slip line between the ash/silt dike cover and the clay base. Test section 9 of flume 1 (right) and flume 2 (left) after the $5^{\text {th }}$ TD (veg.)

mean flow velocity was difficult, (v) the measurement of soil loss/gain in the single test sections in only five points with the pin profiler limits accurate data collection, (vi) only short-term experiments have been carried out.

The benefit of large-scale overflowing experiments on an upstream dike embankment is that the dike-specific erosion resistance can be identified in the field, and that real boundary conditions are considered, such as construction material, additives, vegetation, slope inclination, and discharge parameters, among others. The following conclusions can be drawn from the tests:

1. Particularly designed mixtures of sand/silt, coal combustion ashes and binders can provide a high erosion resistance and stability to a dike cover.

2. If well compacted over the whole surface, these composite materials can function at least as good as a well-chosen clay cover. 
3. Still, the most important factor for erosion protection of the dike cover is an additional grass cover (if not a revetment).

4. Areas with lower compaction/stability of the composite material can trigger the failure of the above grass cover, particularly if the chosen top soil layer is too thin.

5. The use of rolled turf on top of an ash/silt dike cover is not recommended.

6. To establish a good grass cover on top of an ash/ silt composite with its pozzolanic characteristics, a top soil layer of $20-40 \mathrm{~cm}$ is recommended to guarantee sufficient moisture and nutrient supply and a good root development.

7. To prevent this top soil layer from sliding on the distinct slip plane of the ash/silt embankment, either a benching technique (building horizontal steps along the slope) or the use of alternative sliding prevention technologies, such as geosynthetic erosion control mats, are recommended.

8. In case of a failed turf, the advantage of a welldesigned ash composite material over a clay (in terms of stability and erosion resistance) particularly shows on uneven surfaces, e.g. if impairments such as low compaction, installations, stones and other foreign subjects lead to local scouring.

9. Both in case of flume testing and in a real dike embankment a good connection of the cover material and the existing or constructed base material (in this case a $50 \mathrm{~cm}$ thick clay liner) needs to be ensured, either by integrating the cover material into the ground or by the use of other technical measures, such as geosynthetic reinforce-ment, particularly if overflowing water is expected.

10. With the ASTM D6460-12 (2008) standard test method a critical amount of soil loss could be determined in both flumes and under both conditions (vegetated and unvegetated). However, this is only a selective result of five point measurements at the respective upper boundary of the test sections. The use of erosion numbers according to van der Meer et al. (2010) to evaluate the single test sections before and after an overflowing provides a better picture of the quality of the slope condition.

\section{Acknowledgements}

The authors would like to thank the European Union, South Baltic Programme (ERDF) for the partial financing of the project DredgDikes through the years 2010-2015.

\section{References}

ASTM D6460-12. 2008. Standard Test Method for Determination of Rolled Erosion Control Product (RECP) Performance in Protecting Earthen Channels from Stormwater-Induced Erosion. ASTM International. West Conshohocken. 9 p.

Balachowski, L.; Sikora, Z. 2013. Mechanical properties of bottom ash - dredged material mixtures in laboratory tests, Studia Geotechnica et Mechanica 35(3): 3-11. http://dx.doi.org/10.2478/sgem-2013-0026

NTPEP. 2013. National Transportation Product Evaluation Program - Erosion Control Products (ECP). Reports [online], [cited 23 January 2014]. Available from Internet: www.ntpep.org/Pages/ECP.aspx

Olschewski, J.; Cantré, S.; Saathoff, F. 2014. Overflowing tests on the Rostock DredgDikes Research Dike, in Proceedings of the South Baltic Conference on Dredged Materials in Dike Construction, 10-11 April 2014, Rostock, Germany, 67-74.

Ossowski, R.; Sikora, Z.; Duszyński, R.; Sawicki, J. 2014. Investigation on water infiltration and water content changes in a large-scale experimental test dike, in Proceedings of the South Baltic Conference on Dredged Materials in Dike Construction, 10-11 April 2014, Rostock, Germany, 47-51.

Saathoff, F.; Cantré, S.; Sikora, Z. 2015a. South Baltic guideline on the application of dredged materials, coal combustion products and geosynthetics in dike construction. Rostock. 100 p.

Saathoff, F.; Cantré, S.; Sikora, Z. 2015b. South Baltic guideline on the application of dredged materials, coal combustion products and geosynthetics in dike construction: Annex II Scientific Background. Rostock. 65 p.

Sikora, Z.; Ossowski R. 2013. Geotechnical aspects of dike construction using soil-ash composites, Procedia Engineering 57: 1029-1035.

Tefra A silicious aggregate to be used in geotechnical works [online], [cited 23 January 2014]. Available from Internet: http://www.eng.ekotech.pl/products

van der Meer, J. W.; Hardeman, B.; Steendam, G. J.; Schüttrumpf, H.; Verheij, H. 2010. Flow depths and velocities at crest and inner slope of a dike, in theory and with the Wave Overtopping Simulator, in 32nd International Conference on Coastal Engineering, 30 June - 5 July 2010, Shanghai, China. 
Jan OLSCHEWSKI. Doctoral candidate at the Chair of Geotechnics and Coastal Engineering, Universität Rostock, Germany. M.Sc. in Environmental Engineering (Landeskultur und Umweltschutz). Research interests include erosion control, hydraulic experiments and sealing systems under railway tracks.

Stefan CANTRÉ. Scientist and former coordinator of the DredgDikes project at the Chair of Geotechnics and Coastal Engineering, Universität Rostock, Germany. Dr Ing. ( $\mathrm{PhD})$ at Rostock University. Research interests include earth constructions, dredged materials, flume experiments, geosynthetics and erosion control.

Fokke SAATHOFF. Full Professor and Leader of the Chair of Geotechnics and Coastal Engineering, Universität Rostock, Germany. Dr Ing. (PhD) at Hannover University (Franzius-Institut). Research interests include geosynthetics in geotechnical and hydraulic applications, coastal constructions, sealing systems (railway tracks, tunneling, landfills), as well as mineral and synthetic filters (e.g. navigation canals).

Remigiusz DUSZYŃSKI. Scientist and lecturer at the Department of Geotechnics, Geology and Maritime Engineering, Gdansk University of Technology, Poland. Dr inż. (PhD) at Gdańsk University of Technology. Research interests include geotechnical and hydraulic engineering, drainage systems and flood control systems.

Rafal OSSOWSKI. Scientist and lecturer at the Department of Geotechnics, Geology and Maritime Engineering, Gdansk University of Technology, Poland. Dr inż. (PhD) at Gdańsk University of Technology. Research interests include soil mechanics, numerical modeling of soil deformation, mechanics and application of anthropogenic materials. 